\title{
ACOSO Y VIOLENCIA POLÍTICA. TESTIMONIOS DE SÍNDICAS Y REGIDORAS VERACRUZANAS
}

\section{POLITICAL HARASSMENT AND VIOLENCE : TESTIMONIES BY SÍNDICAS AND REGIDORAS IN VERACRUZ}

\author{
Dalia Barrera-Bassols* \\ División de Posgrado. Escuela Nacional de Antropología e Historia/GIMTRAP A.C. Periférico \\ Sur y Zapote s/n. Col. Isidro Fabela. 14030. México, D.F. (barreradi2013@gmail.com)
}

\begin{abstract}
RESUMEN
El artículo presenta resultados de una investigación más amplia sobre la incursión de las mujeres en los cargos de síndica y regidora en los cabildos veracruzanos. Se centra en las experiencias de violencia y acoso político recabadas a través de los testimonios de tres síndicas y 29 regidoras asistentes a un Encuentro estatal de mujeres en el cabildo, realizado por el Instituto Veracruzano de las Mujeres con el apoyo de GIMTRAP A.C. en la ciudad de Xalapa en octubre de 2009. Se busca visibilizar y documentar esta grave problemática, dando la voz a las propias actoras, focalizando la mirada no tanto en los obstáculos vividos para llegar al cargo, sino en aquellos que fueron superados para ejercerlo.
\end{abstract}

Palabras clave: cabildo, cargos de elección, exclusión, mujeres, violencia política.

\section{INTRODUCCIÓN}

$\mathrm{E}$ n el transcurso de la compleja y azarosa transición democrática en México se crean condiciones que permiten hacer una reflexión sobre el acceso limitado que tienen las mujeres a los cargos de elección popular en los diversos órdenes de gobierno (federal, estatal y municipal), a la par que se desatan procesos que, de manera dispar, van abriendo oportunidades para que la proporción de mujeres con cargos de elección haya ido avanzando, de manera que en 2012 constituían: $32.8 \%$ de los senadores, $31.8 \%$ de los miembros de la Cámara de Diputados y $25.0 \%$ de los diputados en Congresos locales, en tanto que en el Distrito Federal representaban: $31.2 \%$ de los Jefes Delegacionales y $33.3 \%$ de los diputados de la

* Autor responsable * Author for correspondence. Recibido: febrero, 2014. Aprobado: mayo, 2014.

Publicado como ARTÍCULO en ASyD 11: 249-270. 2014.

\section{Abstract}

The article presents results from a broader research project on the incursion of women in the positions of sindica (trustee) and regidora (councilor) in Veracruz town councils. It centers on the experiences of political violence and harassment gathered from the testimony of three sindicas and 29 regidoras who attended a state meeting of women in town councils, organized by the Veracruz Women's Insitute (Instituto Veracruzano de las Mujeres), with support from GIMTRAP A.C., in the city of Xalapa in October 2009. It is sought to make visible and document this grave problem, giving voice to the actors themselves, focusing not only on the obstacles experienced to gain access to the position, but also to those that were overcome to exercise it.

Key words: town council, election positions, exclusion, women, political violence.

\section{INTRODUCTION}

$\mathrm{D}$ uring the course of the complex and perilous democratic transition in México, conditions were created that allow reflecting upon the limited access that women have to positions of popular election in the different orders of government (federal, state, municipal), at the same time that processes are unleashed which open opportunities for the proportion of women with election positions to advance, in an uneven manner, so that in 2012 they were: $32.8 \%$ of senators, $31.8 \%$ of members of the House of Representatives and $25 \%$ of representatives in local Congresses, while in Distrito Federal they represented: $31.2 \%$ of the Chiefs of Delegations and $33.3 \%$ of representatives in the Distrito Federal Legislative Assembly, according to data by the National Women's Institute (Instituto Nacional de Mujeres). 
Asamblea Legislativa del Distrito Federal, de acuerdo con datos del Instituto Nacional de las Mujeres.

Paradójicamente, siendo el gobierno municipal la instancia gubernamental con la que las mujeres entran en contacto de manera cotidiana en tanto que ciudadanas, y a partir de su papel de madres y esposas, la presencia femenina en el poder ejecutivo de los gobiernos municipales como presidentas municipales) se mantuvo entre $3 \%$ y $5 \%$, por más de tres lustros, denotando un profundo atraso y estancamiento en el proceso de democratización de este orden de gobierno desde el punto de vista de la pluralidad de género, aunque en el último lustro se ha reportado un pequeño avance, pasando a constituir $6.5 \%$ en un registro para diciembre de 2012, de acuerdo con datos del Instituto Nacional de las Mujeres (Barrera y Massolo, 2003). Sin embargo, en los cargos de menor poder, como el de síndica y, más aún, en las regidurías, sí se ha dado un incremento sustancial, de manera que en marzo de 2012 las mujeres representaban $6.8 \%$ del total de presidentes municipales, $24.9 \%$ de los síndicos y $37.0 \%$ de los regidores, de acuerdo con datos del Instituto Nacional de las Mujeres y del Centro de Estudios para el Adelanto de las Mujeres y la Equidad de Género de la Cámara de Diputados.

De esta manera, en nuestro país, en los ayuntamientos ya se ha venido conformando un sector femenino que podría jugar un papel muy importante en el impulso de políticas públicas de equidad de género, orientando al municipio hacia un desarrollo sustentable con equidad social, étnica y de género (Barrera, 2011b).

A la fecha, en México contamos con bibliografía especializada acerca de los perfiles, trayectorias y experiencias de gobierno de las presidentas municipales que han gobernado diversos municipios en distintas entidades de nuestro país. Algunos inclusive se han dirigido a conocer las experiencias de las presidentas municipales en Veracruz (Rodríguez, 2000; Rodríguez y Cinta, 2003; Sam, 1998; 2000). Sin embargo, son muy escasos los trabajos que han avanzado en la visibilización y el análisis de la presencia creciente de mujeres en otros dos cargos dentro del cabildo: el de síndica y el de regidora, así como el de un aspecto central, como son los obstáculos y las experiencias de acoso político y violencia política vividos en muchos casos al llegar al cargo (Sam, 2003; Valadez, 2003; Barrera, 2008; Barrera, 2011a; Barrera, Aguirre y
Paradoxically, although the municipal government is the government instance which women come into contact with daily, as citizens and in their role as mothers and wives, the female presence in the Executive Power of municipal governments as Municipal Presidents remained at between $3 \%$ and $5 \%$ for more than 15 years, showing a deep backwardness and stagnation in the democratization process of that level of government from the point of view of gender plurality; however, in the last 5 years a small advancement has been reported, moving into making up $6.5 \%$ of the registry by December 2012, according to data from the National Women's Institute (Barrera and Massolo, 2003). However, in positions of less power, such as sindica and even more as regidoras, there has been a substantial increase, so that in March 2012 women represented $6.8 \%$ of total municipal presidents, $24.9 \%$ of sindicos and $37.0 \%$ of regidores, based on data from the National Women's Institute and the Center for Studies in Women Advancement and Gender Equity (Centro de Estudios para el Adelanto de las Mujeres y la Equidad de Género) of the House of Representatives.

Thus, in México, a feminine sector has been developing in local governments that could play a very important role in gender equity public policies, directing the municipality towards sustainable development with social, ethnic and gender equality (Barrera, 2011b).

To date, in México there is specialized bibliography regarding the profiles, trajectories and experiences in government of municipal female presidents who have ruled various municipalities in different states in the country. Some have even been directed at understanding the experiences of municipal female presidents in Veracruz (Rodríguez, 2000; Rodríguez and Cinta, 2003; Sam, 1998; 2000). However, studies that have advanced in making visible and analyzing the growing presence of women in two other positions within the town council, are very scarce: that of sindica and regidora, as well as about a central aspect like the obstacles and experiences of political harassment and political violence experienced in many cases when the position is attained (Sam, 2003; Valadez, 2003; Barrera, 2008; Barrera, 2011a; Barrera, Aguirre and Casas, 2008; Barrera and Suárez, 2012; Massolo, 2004; 2008).

This study is directed at analyzing the feminine experience in town councils of municipalities in the 
Casas, 2008; Barrera y Suárez, 2012; Massolo, 2004; 2008).

El presente trabajo se dirige al análisis de la experiencia femenina en los cabildos de los municipios del estado de Veracruz, centrándonos en los testimonios de tres síndicas y 29 regidoras asistentes al Encuentro Estatal de Presidentas Municipales, Síndicas y Regidoras de los Gobiernos municipales del estado de Veracruz, convocado por el Instituto Veracruzano de las Mujeres, con apoyo del Grupo Interdisciplinario sobre Mujer, Trabajo y Pobreza, GIMTRAP A.C. en octubre de 2009 (Barrera, 2009). En particular, nuestro trabajo se enfoca a las experiencias relatadas en cuanto a los obstáculos enfrentados en el ejercicio del cargo y en particular, a los casos de acoso político y de violencia política.

Esperamos que este trabajo constituya un aporte a la visibilización de dicha problemática y a la reflexión sobre sus raíces dentro de una cultura política predominante, de tipo autoritario, sexista y antidemocrático, que prevalece en todos los espacios de la vida social y política en nuestro país, y cuya gravedad ha llevado a la propuesta y aprobación en el Senado de la República de la inclusión de la "Violencia política de género" en la Ley General de Acceso de las Mujeres a una Vida Libre de Violencia, así como en el Código Federal de Instituciones y Procedimientos Electorales. (Cimacnoticias, México, DF. 21/03/2013).

\section{EL DIFÍCIL ACCESO DE LAS MUJERES VERACRUZANAS AL CABILDO: PRESIDENTAS MUNICIPALES, SÍNDICAS Y REGIDORAS}

Para ubicar los testimonios de las síndicas y regidoras de estudio, hemos primero de dar una mirada al grado de avance de la incursión femenina en los cargos de elección a nivel municipal en el estado de Veracruz. Analizando la información desglosada por municipio del Sistema Nacional de Información $\mathrm{Mu}$ nicipal (consulta del 2 de octubre de 2008) encontramos que, en octubre de 2008, 147 (69.3\%) de los 212 municipios veracruzanos tenían una o más mujeres con el cargo de presidenta municipal, síndica o regidora, lo que implica que $30.7 \%$ de los municipios veracruzanos no tenían a ninguna mujer en dichos cargos, por lo que 65 cabildos estaban conformados únicamente por hombres.

La composición de la presencia femenina en los cargos del cabildo era la siguiente: 17 mujeres eran state of Veracruz, focusing on the testimonies of three sindicas and 29 regidoras who attended the State Meeting of Municipal Presidents, Union Members and Councilors (Encuentro Estatal de Presidentas Municipales, Sindicas y Regidoras) of the municipal governments in the state of Veracruz, organized by the Veracruz Women's Institute, with support from the Interdisciplinary Group on Women, Work and Poverty (Grupo Interdisciplinario sobre Mujer, Trabajo y Pobreza, GIMTRAP A.C.) on October 2009 (Barrera, 2009). In particular, our study is focused on the experiences described in terms of obstacles faced in the exercise of the position and, in particular, the cases of political harassment and political violence.

We expect this study to constitute a contribution to making this problem visible and to reflecting upon its roots within a predominant political culture that is authoritarian, sexist and anti-democratic, prevailing in all the social and political life spaces in our country, and whose seriousness has led to the proposal and approval in the Republic's Senate of the inclusion of "Gender political violence" in the General Law for Women's Access to a Life Free of Violence (Ley General de Acceso de las Mujeres a una Vida Libre de Violencia), as well as in the Federal Code for Electoral Institutions and Procedures (Código Federal de Instituciones y Procedimientos Electorales) (Cimacnoticias, México, DF. 21/03/2013).

\section{The DifFicult aCCESS OF VeracruZ WOMEN TO THE TOWN COUNCIL: MUNICIPAL PRESIDENTS, TRUSTEES AND COUNCILORS}

To place the testimonies of sindicas and regidoras in the study, we must first take a glance at the degree of advancement of female incursion into election positions at the municipal level in the state of Veracruz. Analyzing the information broken down by municipality in the National Municipality Information System (Sistema Nacional de Información Municipal) (consulted on October 2, 2008), we found that in October 2008, 147 (69.3\%) of the 212 municipalities in Veracruz had one or more women with the position of municipal president, sindica or regidora, which implies that $30.7 \%$ of the municipalities in Veracruz did not have any women in these positions, so that 65 town councils were made up solely of men.

The composition of female presence in the town council positions was the following: 17 women were 
presidentas municipales, representando tan sólo $8.0 \%$ del total estatal; 33 síndicas constituían $15.6 \%$ del total y 187 regidoras representaban $29.4 \%$ del total. De esta manera, de 1060 cargos, 237 eran ocupados por mujeres, las que representaban $22.4 \%$ del total estatal. (Cuadro 1).

Como señalara Massolo (1998), un aspecto que incide en el acceso de las mujeres a los cargos de presidenta municipal, síndica y regidora es el avance en la democratización de la vida municipal en cuanto a la pluralidad y alternancia en el poder. De acuerdo con datos de octubre de 2008, $89.0 \%$ de las presidentas municipales veracruzanas en funciones habían sido postuladas por la Coalición Alianza Fidelidad por Veracruz (PRI y PVEM, para elecciones municipales); $78.8 \%$ de las síndicas y $41.7 \%$ de las regidoras ganadoras fueron postuladas por la misma coalición. El Partido Acción Nacional postuló a 5.5 \% de las presidentas municipales ganadoras, $6.1 \%$ de las síndicas y $30.0 \%$ de las regidoras. Por su parte, el Partido de la Revolución Democrática postuló a $5.5 \%$ de las presidentas municipales ganadoras, $3.0 \%$ de las síndicas que llegaron al cargo y $10.2 \%$ de las regidoras, en tanto que la Coalición Alianza por el Bien de Todos y el Partido Revolucionario Veracruzano aportaron 3. $8 \%$ de las regidoras electas, respectivamente; el Partido Convergencia postuló a $5.9 \%$ de las regidoras ganadoras y a 9.1 de las síndicas.

Vemos así que el mayor avance hacia la pluralidad política en los cargos del cabildo se dio en las regidurías. Si consideramos el conjunto de mujeres con cargo en los cabildos de los gobiernos municipales del estado de Veracruz tenemos que $50.1 \%$ de éstos correspondieron a la Coalición Alianza Fidelidad por Veracruz; $24.9 \%$, al PAN; $8.9 \%$, al PRD; $5.9 \%$, al Partido Convergencia; y $3.0 \%$ al Partido Revolucionario Veracruzano y a la Coalición por el Bien de Todos, con una presencia marginal de otros cuatro partidos. Resulta entonces que, a pesar de que prevalece la hegemonía priísta, expresada en la inexistencia hasta ahora de alternancia partidista en el ejecutivo estatal y en el hecho de que es el partido que impulsara la candidatura de $89 \%$ de las presidentas municipales, se han ido abriendo espacios de alternancia en los cargos de síndico y, en especial, en las regidurías, resquicio por el cual se introducen las mujeres. (Cinta, 2007).

El panorama hasta aquí esbozado presenta los avances relativos ocurridos en el acceso de las mujeres
Cuadro 1. Veracruz Mujeres con cargo en el cabildo Octubre de 2008.

Table 1. Veracruz Women with positions in the town council. October 2008.

\begin{tabular}{lrcc}
\hline Cargo & Total & Mujeres & \%Mujeres \\
\hline Presidentes municipales & 212 & 17 & 8.0 \\
Síndicos & 212 & 33 & 15.6 \\
Regidores & 636 & 187 & 29.4 \\
\hline Total & 1060 & 237 & 22.4 \\
\hline
\end{tabular}

Fuente: elaboración propia, con base en datos del Sistema $\mathrm{Na}$ cional de Información Municipal; consulta del 2 de octubre de 2009. - Source: author's elaboration, based on data from the National Municipal Information System; consulted on October 2, 2009 .

municipal presidents, representing only $8.0 \%$ of the state total; 33 sindicas made up $15.6 \%$ of the total and 187 regidoras represented $29.4 \%$ of the total. Thus, of 1060 positions, 237 were occupied by women, representing $22.4 \%$ of the state total (Table 1 ).

As pointed out by Massolo (1998), an aspect that influences the access of women to the positions of municipal president, sindica and regidora is the advance in democratization of municipal life in terms of plurality and power alternation. According to data from October 2008, $89.0 \%$ of the female municipal presidents in Veracruz in functions had been postulated by the Coalición Alianza Fidelidad por Veracruz (PRI and PVEM political parties, for municipal elections); $78.8 \%$ of the sindicas and $41.7 \%$ of the regidoras who won were postulated by the same coalition. Partido Acción Nacional (PAN) postulated $5.5 \%$ of the winning female municipal presidents, $6.1 \%$ of the sindicas and $30.0 \%$ of the regidoras. In its turn, Partido de la Revolución Democrática (PRD) postulated $5.5 \%$ of the winning female municipal presidents, $3.0 \%$ of the sindicas who attained the position and $10.2 \%$ of the regidoras, while Coalición Alianza por el Bien de Todos y el Partido Revolucionario Veracruzano contributed $3.8 \%$ of the elected regidoras, respectively; Partido Convergencia postulated $5.9 \%$ of the winning regidoras and $9.1 \%$ of the sindicas.

Thus, we can see that the greatest advancement towards political plurality in the town council positions took place in the councilor (regidora) positions. If we consider the set of women with positions in the town councils of municipal governments in Veracruz, we find that $50.1 \%$ of these 
veracruzanas a los cargos de presidenta municipal, síndica y regidora, mostrando evidencias de mayor dificultad, en relación con el peso de cada cargo dentro del gobierno municipal. Así, el cargo de regidora es más accesible, el de síndica mucho menos, con una carga importante de poder, y muy marginalmente accesible, el de presidenta municipal, el de mayor poder.

De otra parte hemos de remarcar que, como lo muestran los testimonios de síndicas y regidoras, los mecanismos de exclusión de las mujeres del poder político (que parten de la representación del poder político como una característica masculina, y del espacio de la política como un espacio "masculino"), operan tanto en el entorno cultural, familiar y comunitario en los partidos políticos, como en el espacio mismo del gobierno municipal, incluyendo el cabildo y la administración municipal. Dichos mecanismos se hacen presentes tanto en las dificultades para el acceso al cargo, como en el ejercicio de éste, llevando a desarrollar diversas estrategias para enfrentar el duro reto que implica ser mujer y presidenta municipal, síndica o regidora.

Las funciones del síndico tienen una relevancia especial, otorgándole a éste el poder para vigilar la correcta recaudación y aplicación de los fondos públicos municipales, revisar y suscribir con su firma los estados de origen y aplicación de fondos, así como la cuenta pública municipal y los estados financieros; fungirá además como Agente del Ministerio Público y tendrá la representación legal del Municipio. No es de extrańarse que este sea un cargo todavía muy cerrado a las mujeres, aunque se ha ido recurriendo a ellas cada vez más en la búsqueda de una imagen o realidad de honradez y honorabilidad. Finalmente, en la composición del Ayuntamiento están los regidores, representantes de la comunidad en este espacio de toma de decisiones. (Grupo Parlamentario del PRD, 2000; Enzástiga, 2002; Acosta, 2003; Herrasti, 2003).

Como veremos, en el cumplimiento de sus funciones, síndicas y regidoras encuentran una serie de obstáculos, presiones e incluso amenazas relacionadas con la toma de decisiones colegiada, así como con la vigilancia del adecuado y eficiente uso de los recursos del gobierno municipal, comenzando por el ocultamiento y la renuencia a dejarlas acceder a las cifras y a los datos correspondientes. El trabajo conjunto del presidente municipal, el síndico y los regidores, corresponded to the Coalición Alianza Fidelidad por Veracruz; $24.9 \%$, to PAN; $8.9 \%$, to PRD; $5.9 \%$, to Partido Convergencia; and $3.0 \%$ to Partido Revolucionario Veracruzano and Coalición por el Bien de Todos, with a marginal presence of four other parties. It turns out, then, that in spite of the PRI hegemony prevailing, expressed in the inexistence so far of party alternation in the state executive and the fact that it is the party that drove the candidacy of $89 \%$ of the female municipal presidents, alternation spaces for the positions of sindico and, particularly, for regidores, have been opening, margin where women have been introduced (Cinta, 2007).

The panorama so far described presents the relative advances that have occurred in the access of Veracruz women to positions of municipal president, sindica and regidora, showing evidence of greater difficulty in regard to the weight of each position within the municipal government. Thus, the position of regidora is more accessible, of sindica much less, with an important load of power, and that of municipal president, of greatest power, quite marginally accessible.

On the other hand, we should mention that as the testimonies of sindicas and regidoras show, the exclusion mechanisms of women in political power (which stem from the representation of political power as a masculine characteristic, and the space of politics as a "masculine" space), operate both in the cultural, family and community environment in political parties, and in the very space of the municipal government, including the town council and the municipal administration. These mechanisms are present both in the difficulties for access to the position and in its exercise, leading to the development of diverse strategies to face the tough challenge of being a woman and municipal president, sindica or regidora.

The functions of sindico have a special importance, granting he/she the power to watch over the proper collection and application of municipal public funds, review over and subscribe with their signature the origin and application statements of municipal public funds, as well as the municipal public account and the financial statements; he/she will also serve as Public Prosecutor Agent and will have the legal representation of the municipality. It should come as no surprise that this is a position that is still quite closed off to women, although they 
y su apertura a la expresión y participación ciudadana, darán por resultado una adecuada comunicación y capacidad de resolución de las problemáticas de los diversos sectores de la comunidad, incluidas las mujeres. De cualquier manera, en nuestro país, en la mayoría de los municipios todavía se está lejos de contar con un funcionamiento democrático, eficiente y eficaz de los cabildos en su toma de decisiones.

\section{SÍNDICAS Y REGIDORAS VERACRUZANAS EN EL EJERCICIO DEL CARGO}

Nuestra investigación analiza los testimonios de tres síndicas y 29 regidoras, mismos que serán presentados cuidando el anonimato de las informantes en la medida de lo posible, en consideración a la realidad de su entorno y a las posibles repercusiones. En términos cuantitativos las tres síndicas representan $9.1 \%$ de las 33 existentes en ese año, en tanto que las 29 regidoras constituían $15.5 \%$ del total de 187 . Provenían de 29 municipios $(13.7 \%$ del total de municipios de Veracruz), distribuidos en las diez regiones administrativas de Veracruz, representando así, hasta cierto punto, la complejidad y diversidad de los municipios veracruzanos ${ }^{1}$. Se trata pues de presentar una serie de casos que hablan de una situación compartida por buena parte de las mujeres con cargo en el cabildo, en este caso en un estado particular, pero que se repite en las distintas entidades de la República.

\section{Participación en comisiones}

En el cumplimiento de sus funciones las regidoras de estudio participaban en distintas comisiones, ya sea como titulares o en apoyo de los titulares². El panorama del tipo de comisiones en las que se insertaron corresponde a las concepciones "tradicionales" de las capacidades femeninas para desarrollar tareas del cuidado de los otros (salud, asistencia pública, ornato, educación, cultura), contabilizar personas (registro civil, reclutamiento, panteones), cuidar el orden, la limpieza y el entorno (tránsito, limpia, agua potable, drenaje, ecología, centrales de abasto, mercados y rastros) y hacer gestión social (participación ciudadana y vecinal). De otra parte, las áreas de menor participación tienen que ver con concepciones que adjudican las prácticas de gobierno y el manejo del dinero a los varones (gobernación, policía, obras, hacienda, regularización de la tierra, fraccionamientos, have been increasingly sought out in the search for an image or reality of honesty and honor. Finally, in the composition of the City Council, there are regidores, who represent the community in this space for decision-making (Grupo Parlamentario del PRD, 2000; Enzástiga, 2002; Acosta, 2003; Herrasti, 2003).

As we will see, in the fulfillment of their functions, sindicas and regidoras find a series of obstacles, pressures and even threats related to collegiate decision-making, as well as to the vigilance of adequate and efficient use of the municipal government resources, starting with the hiding and reluctance to letting them have access to the corresponding figures and data. The joint work by the municipal president, sindico and regidores, and their openness to citizens' expression and participation, will result in an adequate communication and ability to solve the problems of various sectors of the community, including women. In any case, in our country, in most of the municipalities there is still a long way from having a democratic, efficient and effective functioning of town councils in decision-making.

\section{VERACRUZ SÍNDICAS AND REGIDORAS IN THE EXERCISE OF THEIR POSITIONS}

Our research analyzes the testimonies of three sindicas and 29 regidoras, which will be presented taking care of their anonymity, as far as possible, in consideration to their environment and possible repercussions. In quantitative terms, the three sindicas represented $9.1 \%$ of the 33 there were that year, while the 29 regidoras represented $15.5 \%$ of the 187 total. They were from 29 municipalities (13.7\% of the total municipalities in Veracruz), distributed into the ten administrative regions of Veracruz, thus representing the complexity and diversity of Veracruz municipalities, up to a certain point ${ }^{1}$. Therefore, the purpose is to present a series of cases that shed light on a situation shared by a good part of women with positions in the town council, in this case in a specific state, although this is repeated in different states of the Republic.

\section{Participation in commissions}

In the fulfillment of their functions, regidoras in the study participated in different commissions, whether as incumbents or in support of the incumbent ${ }^{2}$. 
licencias), así como trabajos rudos como los asociados a la protección civil y al fomento agropecuario, etcétera.

Además de ser parte de la Comisión de Hacienda y Patrimonio Municipal, a la cual deben pertenecer por disposición de la ley orgánica municipal, una de las tres síndicas participaba también en la Comisión de Ecología y otra en cinco comisiones más, incluida la de Equidad y Género. Curiosamente, ninguna de las tres mencionó pertenecer a la Comisión de Gobernación, Reglamentos y Circulares, a pesar de ser obligatorio, según la ley orgánica municipal, resultando interesante el caso de una regidora que mencionó formar parte de esta comisión.

Las regidoras describieron el desempeño en sus comisiones fue de manera diversa. Hubo quienes simplemente no respondieron la pregunta (tres de las 29 regidoras) o que contestaron aludiendo a que les gustaban mucho sus comisiones, pero sin especificar el trabajo que desarrollaban en ellas (11 de las 29 regidoras). Algunas mencionaron tener problemas para desarrollar sus comisiones, debido a una mala relación con el alcalde o con miembros del cabildo. Ante la falta de apoyo del alcalde, muchas regidoras generan estrategias para apoyarse con su red de conocidos, amigos, familiares, etcétera, así como para bajar recursos del gobierno estatal o federal, e incluso ponerlos de su bolsillo para cumplir con los trabajos de su cargo. Las formas de boicot mencionadas fueron el negarles los recursos, información y datos, y recibir discriminación por ser de oposición o por ser mujer, entre otras.

\section{Obstáculos y acoso político enfrentados en el ejercicio del cargo}

Al igual que las síndicas, en el ejercicio del cargo y en las comisiones asignadas o de las cuales forman parte, las regidoras enfrentan diversos obstáculos y situaciones adversas asociadas con el entorno cultural machista, descrito por ellas bajo la forma del bloqueo y el escepticismo en cuanto a las acciones emprendidas a favor de las mujeres y de la Equidad de Género que se vive en el Ayuntamiento y en las Direcciones con las que entran en contacto. De las 29 regidoras, dos no contestaron la pregunta sobre los obstáculos enfrentados en el cargo y solamente seis respondieron que no los habían sentido, con testimonios como el siguiente: "No he enfrentado obstáculos, tengo el
The panorama of the type of commissions where they were inserted corresponds to the "traditional" conceptions of the feminine capacities to develop tasks in the care of others (health, public assistance, decoration, education, culture), count people (civil registry, recruiting, graveyards), keeping the order, cleanliness and environment (transit, cleaning, drinking water, drainage, ecology, supply centers, markets and slaughterhouses), and social management (citizen and neighbor participation). On the other hand, the areas of least participation are related to conceptions that attribute the practices of government and management of money to males (governance, police force, public works, taxes, land regularization, residential development, licenses), as well as rough tasks such as those associated to civil protection and agricultural promotion, etcetera.

In addition to being part of the Commission of Taxes and Municipal Patrimony, to which they must belong as a ruling by the municipal organic law, one of the three sindicas also participated in the Ecology Commission and another in five more commissions, including the one on Equity and Gender. Oddly enough, none of the three mentioned belonged to the Commission on Governance, Regulations and Notices, in spite of this being mandatory, according to the municipal organic law, making the case of a regidora who mentioned belonging to this commission interesting.

The regidoras described the performance of their commissions in a diverse manner. There were those who simply did not respond to the question (three of the 29 regidoras) or who answered referring that they liked their commissions very much, without specifying the task they carried out in them (11 of the 29 regidoras). Some mentioned having trouble developing their commissions, because of a bad relationship with the mayor or members of the town council. Facing the lack of support from the mayor, many regidoras generate strategies to be supported by their network of acquaintances, friends, relatives, etcetera, as well as to obtain resources from the state or federal government, and even by paying from their own pocket to fulfill the tasks of their position. The boycott actions mentioned were denying resources, information and data, and being discriminated against because of belonging to the opposition or being a woman, among others. 
apoyo condicional de todos mis compañeros y los ciudadanos de (...) me aprecian bastante".

Hubo quien refirió explícitamente no haber tenido problemas en el Ayuntamiento, incluso siendo regidora de oposición:

Gracias a Dios tengo una buena comunicación con el presidente municipal, que me ayuda con mis mujeres. No me puedo quejar de él porque solo es necesario que yo abra la boca y me apoya; me siento contenta del momento en que llegué a ser regidora porque soy apoyada por el presidente municipal, que es panista. Gracias a Dios me apoya en todo.

Expresiones como las anteriores no fueron predominantes; sin embargo, hubo múltiples testimonios de diversas formas de lo que se ha calificado como "acoso político", definido por la Asociación de Concejalas de Bolivia como:

"El acto o conjunto de actos cometidos por una persona, directamente o a través de terceros, en contra de una mujer o de su familia, con el propósito de impedir o inducir a una acción u omisión en el cumplimiento de sus funciones, derechos o deberes mediante actos de presión a través de persecución, hostigamiento o amenazas efectuadas por cualquier medio" (ACOBOL, 2007).

Tres cuartas partes de las ediles del estudio mencionaron haber enfrentado diversos obstáculos en el ejercicio del cargo e hicieron referencia a distintas problemáticas. Una de las más mencionadas por las síndicas y regidoras es la escasez de recursos para la realización de su trabajo en comisiones, como lo ilustra incluso una síndica del único municipio con grado de marginación muy bajo: "Aunque realmente no veo muchos obstáculos, el principal ha sido el recurso económico; estoy muy cerca de la capital, todo el apoyo que he necesitado de las instancias, de las agencias del Ministerio Público lo he tenido, lo he buscado, así que puedo decir que mi principal problema es el económico".

Las regidoras confrontaron otras de las problemáticas con el presidente municipal, el síndico o los demás regidores, así como en ocasiones con los directores de las áreas de sus comisiones. Dichos conflictos se expresaron en actos de discriminación: por ser mujer, por ser joven, por pertenecer a la oposición o a otro grupo dentro del mismo partido que gobierna el municipio, e inclusive en un caso, por ser mujer o tener alguna discapacidad. Un ejemplo de la discriminación es el

\section{Obstacles and political harassment faced in the exercise of the position}

Just like the sindicas, in the exercise of the position and commissions assigned, or those they belong to, regidoras face diverse obstacles and adverse situations associated with the chauvinistic cultural environment, described by them as blockage and skepticism in terms of the actions undertaken in favor of women and Gender Equity experienced in the Town Council and in the Directions with which they have contact. Of the 29 regidoras, two did not answer the question about the obstacles faced in the position and only six responded that they had not felt them, with testimonies such as the following: "I haven't faced obstacles; I have the unconditional support of all my coworkers and citizens in (...) who appreciate me quite much".

There were those who explicitly referred not having issues in the Town Council, even as a regidora from the opposition:

Thank God I have good communication with the municipal president, who helps me with my women. I can't complain about him because as soon as I open my mouth he supports me; I feel happy since the moment I became regidora because I am backed by the municipal president, who is from the PAN. Thank God, he supports me in everything.

Expressions such as these were not predominant; however, there were multiple testimonies in various manners of what has been qualified as "political harassment", defined by the Association of Female Council Members in Bolivia as:

"The act or set of acts performed by a person, directly or through third parties, against a woman or her family, with the purpose of preventing or inducing an action or omission in the fulfillment of her functions, rights or duties through acts of pressure, through persecution, harassment or threats performed by any means" (ACOBOL, 2007).

Three fourths of the female council members in the study mentioned having faced various obstacles in the exercise of their position, and they referred to 
no escuchar su voz, hacer caso omiso a sus propuestas en el cabildo: "En las reuniones de Cabildo, mi idea a veces no es tomada en cuenta porque soy mujer, pero aun así yo siento que tengo la capacidad y por eso estoy donde estoy".

Una situación especialmente difícil es la de ser regidora joven, ya que por esa razón los varones las "quieren chamaquear", como señalan tres de ellas, ligado este prejuicio al entorno machista:

El obstáculo que he enfrentado es mi edad, ya que es difícil llegar a un cabildo cuando el demás cuerpo edilicio, que está integrado por el síndico, el regidor y el alcalde, te ven como una niña. Tengo 29 años y, entonces, a veces, al hablar con un síndico que tiene 59 ańos, quisiera chamaquearte, pero gracias a Dios soy licenciada en derecho y he tenido que aprender a fundamentar las cosas cuando las solicito; no es fácil, pero tampoco es tan difícil.

No solamente el ser mujer joven con cargo en el cabildo implica enfrentar el "chamaqueo" por parte de los compañeros del cabildo, sino también las dudas que se manifiestan sobre sus capacidades: "Los obstáculos que he enfrentado principalmente fueron ser de oposición, además de mujer y joven porque piensan que por dichas razones no tenemos la capacidad para desarrollar ciertas actividades".

El siguiente es un testimonio de cómo la discriminación de género se manifiesta como discriminación por generación, al aducirse la "falta de experiencia" de una joven regidora:

Soy la única mujer en el cabildo y en total somos tres: el presidente, el síndico y su servidora. En coordinación con el DIF municipal hemos trabajado con el Sistema Nacional de Empleos en los talleres de repostería, costura y piñatas. Es lo único que se ha logrado porque a veces te ponen barreras para no poder trabajar o cuando tú necesitas el apoyo, el hecho de que seas mujer y estar joven ha sido también algo pesado para mí porque piensan que "no tienes experiencia o que no sabes", pero lo estamos demostrando y al final el trabajo se va a ver. Sólo he tenido apoyo del DIF municipal. Como ya comenté, los principales inconvenientes son el hecho de ser joven, ponerme barreras y decirme que no tengo experiencia.

Otra regidora expresa que: "en el cabildo me siento entre machitos". No solamente se les desconocen sus capacidades y no se escucha su voz, sino que se llega a suponer que ellas deberán hacer lo que los hombres del cabildo deseen, presuponiendo que su different problems. One of the most mentioned by sindicas and regidoras is the scarcity of resources for performing their work in commissions, as is even illustrated by a sindica from the only municipality with very low marginalization degree: "Although I really don't see many obstacles, the main one has been financial resources; I am very close to the capital, all the support I have needed from instances like the Public Prosecutor's Office agencies I have had, I have sought it, and so I can say that my main problem is financial".

Regidoras confronted other problems with the municipal president, sindico or other regidores, and sometimes with directors of areas in their commissions. These conflicts were expressed in discriminatory acts: because they are women, because they are young, because they belong to the opposition or another group within the same party that governs the municipality, and in one case, even as a result of being a woman or having a disability. An example of discrimination is not listening to their voices, ignoring their proposals in the town council: "During the meetings of the Town Council, my ideas sometimes are not taken into account because I am a woman, although I still feel that I have the ability and that is why I am where I am”.

A particularly difficult situation is to be a young female regidora, because males want to "take advantage of her" (chamaquear) for this reason, as three of them point out, with this prejudice being linked to the chauvinistic environment:

The obstacle I have faced is my age, since it is difficult to reach the town council when the other members of the council, which is made up of the sindico, the regidor and the mayor, see you as a young girl. I am 29 years old and, so, sometimes, when I speak to a sindico who is 59 years old, he would like to chamaquear me, but thank God I am a lawyer and I've had to learn to support things when I request them; it isn't easy, but it is also not so difficult.

Being a young woman with a position in the town council not only implies facing being taken advantage of by co-members of the council, but doubts are also manifested regarding their abilities: "The obstacles I have faced have been primarily being from the opposition, in addition to a woman and 
posición frente a los conflictos se debe regir por la "lealtad" que le deben a un varón:

Los impedimentos son varios: "he tenido enfrentamiento con el presidente municipal y con el síndico porque me ponen entre la espada y la pared. Uno me dice una cosa y el otro me dice otra; son los retos que he tenido en el Ayuntamiento, que me discriminan por ser mujer y entonces quisieran que yo hiciera lo que ellos dicen. Hasta ahorita ese es mi mayor reto.

El restar legitimidad a su figura como autoridad es otro mecanismo muy común. Por ejemplo, una forma de desconocer sus atribuciones como regidoras es ahuyentar a la gente que llegue a sus oficinas a solicitar atención de algún tipo:

Para mí el machismo ha sido la principal dificultad. En el mismo Ayuntamiento hemos tenido ese tipo de problemas y estamos navegando contra corriente porque, como son la mayoría de hombres, me presionan un poco, tratan de correr a la misma ciudadanía que me va a buscar, que van en chanclas, en short. Ellos ya perdieron el piso, ya no saben quién los puso ahí y es por esa misma gente que estamos ahí y no es justo. El principal obstáculo es que navego contra corriente porque no encuentro ni tengo el apoyo de mis compañeros ediles porque si en realidad nos sumáramos, seríamos uno de los municipios mucho mejores porque estamos mal organizados y si no hay esta organización, no tenemos nada.

La misma regidora señala que no le entregan las invitaciones del Instituto Veracruzano de las Mujeres que le llegan al Ayuntamiento y que no le dan viáticos suficientes, además de otras acciones de hostigamiento que han redundado en que en su Ayuntamiento se desconociera la forma de crear la Instancia Municipal de las Mujeres, asunto sobre el cual el resto del cabildo mostraba un total desinterés.

Esta problemática de no transmitirle a las síndicas y regidoras las invitaciones del Instituto Veracruzano de las Mujeres fue una constante en los diversos recorridos y talleres efectuados en Veracruz por GIMTRAP, A.C., al igual que la de no dotarlas de los recursos necesarios para asistir a los eventos convocados por dicho instituto, muchos de los cuales tenían que ver directamente con capacitación sobre políticas públicas de equidad de género, conformación de la instancia municipal de las mujeres y otros aspectos young, because they think that we don't have the ability to carry out certain activities because of these reasons".

The following is a testimony of how gender discrimination is manifested as discrimination based on the generation, when referring to the "lack of experience" of a young regidora:

I'm the only woman in the town council and in total there are three of us: the president, the sindico and yours truly. In coordination with the municipal DIF we have worked with the National Employment System in workshops for baking, sowing and piñata-making. This is the only achievement because sometimes there are barriers against working, or when you need support, the fact that you're a woman and young has also been somewhat difficult for me, because they think "you don't have any experience or do not know", but we are proving it and in the end the work is going to show. I have only had support from the municipal DIF. As I mentioned, the main inconveniences are the fact that $\mathrm{I}$ am young, setting up barriers and telling me that I am inexperienced.

Another regidora expressed that: "in the town council, I feel I am among little machos". Not only are her capacities ignored and her voice unheard, but they also assume that women should do what men in the town council wish, presupposing that their position in face of conflicts should be ruled by the "loyalty" they owe to a male.

The obstacles are several: "I have had a confrontation with the municipal president and with the sindico because they put me between a rock and a hard place. One of them tells me one thing and the other says something different; these are challenges that I've had at the Town Council: that I'm discriminated against for being a woman and that they would like for me to do what they say. Until now this is my greatest challenge.

Diminishing the legitimacy of their figure as authorities is another very common mechanism. For example, one way of not acknowledging their responsibilities as regidoras is to chase away the people who come to their offices to ask for support of some kind: 
relevantes para el adelanto de éstas en el ámbito municipal.

Resulta significativo que en varios testimonios se señale específicamente el carácter machista del entorno cultural, pues al intentar realizar acciones a favor de las mujeres se topan con la resistencia de los compañeros de éstas, además de que los mismos trabajadores del Municipio, de diversas jerarquías, se resisten a reconocer su investidura, como ilustra una regidora:

Los hombres son un gran obstáculo porque a veces me acerco a platicar con las señoras y las motivo a que salgan adelante, muy independientemente de que tengan que estar con la pareja, porque en mi municipio hay demasiada violencia contra las mujeres; las maltratan bastante y ellas se quedan calladas. Yo me acerco, comento con ellas y sus esposos hasta les prohíben que hablen con nosotros porque les dicen que les estamos abriendo los ojos, que después vamos a mandar nosotras y ellos en qué lugar van a quedar. Sí es un problema; incluso, con el personal que tenemos en el Ayuntamiento se me hace difícil porque hay días en que el alcalde o el síndico tienen que salir a gestionar y cuando yo doy una orden o les digo qué es lo que hay que hacer, me contestan: "a nosotros no nos va a mandar una mujer”. Sí, son dificultades que tengo que enfrentar, pero gracias a Dios mis padres me enseñaron a ser fuerte y ahí estamos. En el cabildo sí cuento con apoyo.

Así, no solamente existen obstáculos y barreras para llegar a algún cargo en el cabildo sino que, incluso llegando a éste, falta todavía asumirlo plenamente y luchar por ser reconocida como figura de autoridad ante el rechazo a que "sea una mujer la que mande".

De las tres síndicas de estudio encontramos que dos de ellas mencionaron que el principal impedimento en el cargo era la falta de recursos en el municipio, en tanto que una más se refirió a las presiones y el hostigamiento, que podríamos calificar como acoso político. El primer caso es el de una regidora que se quejó de que los conflictos partidistas en el cabildo no la dejaban ejercer sus funciones, la desconocían en sus comisiones y le negaban los recursos:

He tenido obstáculos, muchos, porque soy de oposición, porque soy mujer y soy maestra. No
For me, machismo has been the main difficulty. In the Town Council we have had that sort of problem and we are swimming against the current because, since men are the majority, they pressure me, try to chase away the citizens that come looking for me, who come in sandals and shorts. The have lost their ground, they don't remember who put them there, and it is because of those same people that we are there and it's not fair. The main obstacle is that I swim against the current because I can't find and don't have the support of my co-councilors, because if we would come together, really, we would be one of the best municipalities, yet we are badly organized and if there is no organization, we have nothing.

The same regidora points out that they do pass on her invitations from the Veracruz Women's Institute (Instituto Veracruzano de las Mujeres) which arrive at the Town Council, and that she does not get enough travel allowances, in addition to other harassment actions that have resulted in her Town Council ignorign the way of creating the Municipal Women Instance, an issue about which the rest of the council showed a complete lack of interest.

This problem of not transmitting invitations from the Instituto Veracruzano de las Mujeres was a constant in the different visits and workshops carried out in Veracruz by GIMITRAP, A.C., as well as that of not providing the necessary resources to attend the events organized by that institute, many of which had to do directly with training on gender equity public policies, establishing the municipal women's instance and other relevant aspects for their advancement in the municipal environment.

It is significant that in several testimonies the macho character of the cultural environment is signaled specifically, for when trying to perform actions in favor of women they are faced with the resistance from their coworkers, in addition to the municipality workers themselves, from various hierarchical positions, refusing to recognize their investiture, as a regidora describes:

Men are a huge obstacle because sometimes I approach the ladies to talk and I motivate them to pull through, quite independently from having to be with their spouse, because in my municipality there is too much violence against women; they 
me jacto ni me lleno de vanidad, pero la gente que me conoce sabe lo que hago; venimos de la sangre priísta porque nuestros padres también lo fueron; mi papá fue el presidente municipal también aquí y, obviamente, apenas éramos chicos y ya andábamos en la grilla. Por ejemplo, quise hacer una campaña para la basura, de limpiar, chapear, barrer, pintar, de todo, pero me decían: "no, dile al director". Quiero hacer una campaña de reciclado de basura, necesitamos reciclarla, recopilar pilas, y la respuesta es: "dile al Director de Ecología"; todos mis proyectos eran a través de otros. Entonces dije: "ahora no, ahora todos mis proyectos los hago yo" porque la de Seguridad Pública no se la voy a dar a nadie. Cuando yo se los paso ni siquiera me invitan cuando lo van a participar ni me llaman cuando lo están haciendo; entonces no se vale, son mis ideas. Les quiero decir también que no cuento con ningún apoyo económico del Ayuntamiento; todo sale de mi bolsa, y por eso dejé de pedir, porque siempre me dijeron que no y me negaban los apoyos.

Otro testimonio de una regidora de un municipio de fuerte presencia indígena relata los intensos problemas en el cabildo, que han implicado que las dos mujeres en el cabildo, pertenecientes al mismo partido del alcalde, quedasen bloqueadas, no permitiéndoseles incluso firmar las Actas de Cabildo (violentando así la ley orgánica municipal), descalificando a una de ellas, manifestándole que debería "dedicarse a su señor y a sus hijas", pues "ya no estaba en edad" de andar en la política:

Dentro de mis comisiones desgraciadamente no he podido desarrollar la de Equidad de Género como debe de ser, por los mismos problemas que tenemos dentro del municipio ya que, a pesar de que el presidente es del mismo partido, ha tomado represalias porque pertenecemos a grupos diferentes. Las dos mujeres que somos regidoras priístas estamos completamente bloqueadas y no nos permiten ni participar ni firmar las Actas de Cabildo. Los obstáculos que yo he enfrentado ahí son por problemas políticos. Afortunadamente he tenido mucho apoyo del gobierno estatal, pero no del municipal. Las dificultades que he tenido que enfrentar se han relacionado con el hecho de que soy mujer y por cuestiones políticas. Me dicen que debo dedicarme a mi señor, a mis hijas y are quite mistreated and they remain quiet. I approach them, talk to them and their husbands even prohibit them from speaking to us because they say that we are opening their eyes, that we will be in charge later and that what is the place they will have after? It is a problem; even with the staff we have at the Town Council it is difficult because there are days when the mayor or the sindico have to step out to negotiate and when I issue an order or I tell them what to do, they answer: "we will not be ordered around by a woman". Yes, these are difficulties that I must face, but thank God my parents taught me to be strong and we are still there. In the council I do have support.

Thus, there are not only obstacles and barriers to reach a position in the town council, but rather, even when reaching it, coming to terms with it and struggling to be recognized as a figure of authority is still difficult, faced with the rejection of "being a woman in charge".

Of the three sindicas in the study, we found that two of them mentioned that the main obstacle in the position was the lack of resources from the municipality, while another referred to the pressures and harassment, which we can qualify as political harassment. The first case is a regidora who complained that the party conflicts in the town council did not allow her to exercise her functions; they ignored her in her commissions and denied her the resources:

I have had obstacles, many, because I am from the opposition, I am a woman and I am a teacher. I don't mean to boast or be vain, but people who know me know what I do; we come from PRI blood because our parents were also in the party; my father was the municipal president here also and, obviously, we were barely children and were into politics already. For example, I wanted to have a campaign for trash, cleaning, weed, sweep, paint, and everything, but they would say: "no, tell the director". I want to have a campaign for trash recycling, we need to recycle, collect batteries, and the answer is: "tell the Ecology Director"; all my projects were through someone else. So, I said: "not now, now I will carry out all my projects myself", because my idea for Public Safety I will not give to anyone. When I 
a cuidar mi salud, que ya no tengo la edad ni el tiempo para estar en la vida política.

Por su parte, derivado de su intención de cumplir con las responsabilidades de su cargo, una de las síndicas enfrentó el aislamiento, el desconocimiento de su investidura y diversas presiones. Dejaron de pasarle documentos por haber hecho ciertas observaciones a los estados financieros que el presidente municipal le presentaba para firma; la comisión de Hacienda los firmaba y los llevaba directamente al Congreso del Estado, contraviniendo a la ley orgánica municipal.

El haber hecho observaciones ocasionó que ahora no se me permita firmar ningún acta de cabildo ni ningún estado financiero desde diciembre del año pasado, además de que tampoco he sido requerida para los cabildos. Desde luego que ha habido barreras porque finalmente no se me ha permitido ejercer mis funciones.

Esta síndica ubicó el problema en parte, en el consenso de firmar como buenas las Actas de Cabildo y los Estados Financieros por parte del resto del cabildo, aunque cuando denunció en el Congreso del Estado esta irregularidad, le respondieron con ambigüedades, como si quien no cumpliera con sus funciones fuera ella, y no los demás miembros del cabildo, quienes pasaban como buenos documentos que por ley deberían ir firmados (y autorizados, por tanto), por el presidente municipal, por la síndica y por los regidores. Por tanto, señaló las imprecisiones" de la Ley Orgánica del Municipio Libre del Estado de Veracruz, las cuales habrían impedido que el Congreso del Estado interviniera y obligara al Ayuntamiento a respetar la investidura y las funciones de la síndica.

\section{Casos de violencia política}

En los Ayuntamientos las mujeres con cargo llegan a confrontar situaciones de violencia política, de acuerdo con la definición de la Asociación de Concejalas de Bolivia (ACOBOL):

Las acciones o conductas agresivas cometidas por una persona, por sí o a través de terceros, que causen daño físico, psicológico o sexual en contra de una mujer o su familia, en ejercicio de la representación política, para impedir y restringir el ejercicio de su cargo o inducirla a tomar decisiones en contra de su give them over, they don't even invite me when they are going to present them, or when they are actually doing them; so, this is not fair, they are my ideas. I also want to say that I do not have any financial support from the Town Council; everything comes from my pocket, and that's why I stopped asking for it, because they always said no and refused to give me funding.

Another testimony from a regidora of a municipality of strong indigenous presence recalls the intense problems in the town council, which have resulted in the two women in the council, who belong to the same party as the mayor, to be blocked, not allowing them even to sign the Town Council Acts (thus breaking the municipal organic law); one of them has been discredited, telling her that she should be "devoted to her husband and daughters", because she "was not of the age anymore" to be interested in politics:

Within my commissions, unfortunately, I haven't been able to develop Gender Equity as it should, because of the same problems that we have in the municipality, since although the president is from the same party, he has retaliated because we belong to different groups. We (the two women) are regidoras from PRI and we are completely blocked, and they don't allow us to participate or to sign the Town Council Acts. The obstacles that I have faced there are because of political problems. Fortunately I have had much support from the state government, but not the municipal. The difficulties that I've had to face have been related to the fact that I'm a woman and because of political issues. They tell me that I have to devote my time to my husband, my daughters, and take care of my health, since I don't have the age or the time for political life.

In her turn, derived from her intention to fulfill the responsibilities of her position, one of the sindicas faced isolation, lack of recognition of her investiture and diverse pressures. They ceased to give her documents because she made certain observations to the financial statements that the municipal president gave her to sign; the Taxes commission signed them and took them directly to the State Congress, disobeying the municipal organic law. 
voluntad, de sus principios y de la ley. (ACOBOL, 2007).

El primer caso es el de una regidora que entró en conflicto con el presidente municipal al querer ejercer su comisión de Agua Potable, Drenaje y Alcantarillado, tras lo cual le quitó la comisión, ignorándola en cuanto al ejercicio de otra que ella ya tenía, que era la de Turismo, hasta que también se la quitó. Después de diversos enfrentamientos fue objeto de "periodicazos” y de una campaña de desprestigio en la radio por parte del alcalde, trabajando al final solamente en la última que le quedaba, pero sin recursos del Ayuntamiento. Ella llevó su caso al Instituto Veracruzano de las Mujeres y al Congreso del Estado sin obtener resultados:

Al inicio de la administración, cuando se repartieron las comisiones, el presidente municipal me dio la Agua Potable, la de Drenaje y Alcantarillado y la de Turismo. Había muchas quejas relacionadas con el agua, pero yo me di a la tarea de comunicarme con el encargado de la Comisión del Agua; él se dio cuenta de lo que yo estaba haciendo y me dijo: "aquí la única persona que tiene facultades soy yo como Presidente Municipal y tú lo único que tienes que hacer es fiscalizar, pero no tienes nada que hacer en la Comisión de Agua Potable porque es un organismo descentralizado". Yo dije: "Bueno, entonces, ¿para qué me asignas esa comisión si nada tengo que ver yo ahí? Hay quejas y tengo que darles soluciones a la gente". A través de un oficio me dijo que no quería que me metiera porque y entonces me quedó con la Comisión de Drenaje y Alcantarillado y la de Turismo. En esta última no me permitió desempeñarme bien ni me invitó a ninguna reunión; éstas se hacían en diferentes lugares, como Papantla, Poza Rica, Coatzintla, Tecolutla e incluso ahí en el municipio, pero no se me incluía. Un día decidí tomar un curso en el que nos hicieron evaluaciones tanto al inicio como al final; mi calificación fue de siete y por este motivo él se dio a la tarea de desprestigiarme, se fue a la radio y dijo que yo había sacado tres en ese examen y que eso demostraba mi incapacidad para tener la comisión de Turismo, así que me la quitó a través del Cabildo. Convenció a los compañeros de que yo no era competente para eso y que no había disposición por parte mía. Yo le dije: "señor alcalde, tengo
Having made observations resulted in me not being allowed to sign any papers anymore from the town council or any financial statement, since December of last year, and I have also not been invited to the councils. Naturally, there have been barriers because in the end I have not been allowed to exercise my functions.

This sindica located the problem, partly, in the consensus of signing the Town Council Acts and the Financial Statements as good, by the rest of the council, although when she denounced this irregularity to the State Congress, they responded with ambiguity, as if she was the one not fulfilling her functions and not the other members of the council, who passed as good the documents that had to be signed, lawfully (and therefore authorized), by the municipal president, the sindica and the regidores. Thus, she pointed out the "vagueness" of the Organic Law of the Free Municipality of the State of Veracruz (Ley Orgánica del Municipio Libre del Estado de Veracruz), which would have prevented the State Congress from intervening and forcing the Town Council to respect the investiture and functions of the sindica.

\section{Cases of political violence}

In the Town Councils, women with positions can be confronted with situations of political violence, according to the definition by the Female Council Members' Association of Bolivia (Asociación de Concejalas de Bolivia, ACOBOL):

The aggressive actions or conducts performed by a person, by himself or through third parties, which cause physical, psychological or sexual harm against a woman or her family, in the exercise of political representation, to impede and restrict the exercise of her position or induce her to make decisions against her will, her principles and the law (ACOBOL, 2007).

The first case is that of a regidora who struggled with the municipal president when wanting to exercise her commission for Drinking Water, Drainage and Sewage, after which he took the commission from her, ignoring her in terms of the exercise of another commission she had, Tourism, until he also took it from her. After various confrontations she was the object of newspaper stories and a discrediting campaign in the radio from the mayor, in the end 
mucha disposición, más bien es usted el que desde el momento que iniciamos esta administración me ha querido desprestigiar y todo por el hecho de ser de que soy oposición".

En su momento mi partido impugnó las votaciones al PRI por todo lo que hicieron y a raíz de ahí él me empezó a relegar; entonces solo me quedé con la Comisión de Drenaje y Alcantarillado, la cual ha obstaculizado en todo momento. En este caso, en una reunión me dijo: "bueno, es que tú no me has presentado trabajos". "Señor alcalde ¿Cómo te voy a presentar un trabajo si para hacerlo necesito las herramientas necesarias para poderme trasladar? No me proporcionas ni un vehículo para hacer mi rondín; si me voy toda la mañana a supervisar alcantarillas, drenajes y todo eso vas a la radio y dices que no trabajo, que si no me da vergüenza nada más venir y cobrar mi quincena”. En todo momento me ha puesto trabas y me ha desprestigiado con notas periodísticas durante todo el año. Me di a la tarea de hacérselo saber al Congreso y al Instituto, pero la verdad es que no he recibido el apoyo que quisiera y esto me hace sentir impotente porque me pregunto qué estoy haciendo aquí si este hombre no me permite realizar el trabajo que quiero desempeñar. No tengo a poyo de ningún tipo; incluso no me dan ni viáticos, nada.

Otra regidora documenta un caso más de regateo de sus funciones y jaloneo con sus comisiones, actitudes de agresión verbal y discriminación, llegando incluso a interponer una demanda contra el alcalde por no convocarla a las reuniones de cabildo:

Al principio de la administración los primeros quince días hubo una buena relación con el Alcalde. Yo tenía seis comisiones, entre ellas Educación; Agua Potable; Limpia Pública, pero como no accedí al manejo que se quería dar a éstas, el alcalde habló conmigo y me dijo que para justificar mi presencia en el cabildo me iba a asignar la de Participación Ciudadana. Yo me imagino que en la ley orgánica vio que no tenía muchas funciones y decidió asignarme esa y la de Tránsito. En mi municipio no hay tránsito; es más bien un camino que pertenece a la Junta Estatal de Caminos, una vía de paso. Gracias a Dios que yo traté working only in the last commission she had left, but without resources from the Town Council. She took her case to the Veracruz Women's Institute and the State Congress without attaining any results:

At the beginning of the administration, when the commissions were assigned, the municipal president gave me Drinking Water, Drainage and Sewage, and Tourism. There were many complaints related to water, but I took it upon myself to get in touch with the Water Commission representative; he realized what I was doing and he said: "the only person who has authority here is me, as Municipal President, and they only thing you have to do is supervise, but you have nothing to do in the Drinking Water Commission, because it is a decentralized organism". I said: "Well, then, why did you assign me that commission if I don't have anything to do there? There are complaints and I have to find solutions for the people". Through a notice he said that he didn't want me to meddle, and then I could stay on the Drainage and Sewage Commission, and Tourism. In the latter I was not allowed to perform fully and I was not invited to any meetings; these were held in different places, like Papantla, Poza Rica, Coatzintla, Tecolutla, and even here in the municipality, but I was not included. One day I decided to take a course where we were evaluated both at the beginning and the end; my grade was seven and for that reason he set out to discredit me, he went to the radio and said that $I$ had scored a three in that test and that it demonstrated my inability to be in the Tourism commission, so he took it from me through the Town Council. He convinced the coworkers that I was not competent for it and that there was no willingness from my part. I said: "Mr. Mayor, I have much willingness, and it is you who has been out to discredit me from the moment we began this administration, and it is all because I am from the opposition".

At the time, my party challenged the elections against PRI because of all they did and, as a result, he began to relegate me; then I was left only with the Drainage and Sewage Commission, which was obstructed at all times. In this case, at a meeting he said: "well, it's just that you have not 
de informarme en el estado y en otros municipios de la República; descubrí que la Comisión de Participación Ciudadana sirve para muchas cosas y me involucré en todas las áreas: gestionar láminas y despensas, así como pintar parques y balcones; con lo que me proporcionaban otros alcaldes y gente de la sociedad civil pude obtener muchos recursos, pero, lamentablemente, como al alcalde no le vino bien y no quiere a mi partido, inclusive yo como mujer tengo una representación y también me quitó esa comisión.

Tomar la de Tránsito ha sido muy complicado ya que he tenido que hacer las cosas por debajo del agua, prácticamente a escondidas. Voy a las escuelas, pero no hago una gran difusión porque sé que me la pueden quitar en la medida que sepan que yo estoy trabajando en ella. Lo mismo pasa con la de Equidad de Género; no la consideran importante porque aquí eso no existe y yo he recibido mucho maltrato por ser mujer. Inclusive, cuando me asignaron la Comisión del Agua literalmente me lo dijeron: "tú te quedas con la del agua por ser vieja, porque tú vas a tratar con las mujeres, porque es la del chisme y tú puedes lidiar con ellas". Actualmente existe una denuncia de manera penal contra el alcalde porque he asistido a seis sesiones de cabildo en casi dos años. No me citan, me quieren quitar responsabilidad; obviamente hay testigos y gente que está de nuestro lado y nos va a apoyar, pero todo esto provoca un desgaste que a veces ya no se puede manejar y hay que aprender a sobrellevarlo.

El siguiente caso presenta una violencia mayor relacionada con la toma de posesión del cargo de regidora, para descontento de ciertos grupos que la someten a amenazas de muerte, tanto a ella como a su familia. Finalmente, la intervención de un alto mando del ejército y el apoyo del presidente municipal, así como la actitud valiente de la regidora, llevaron al fin de las amenazas, lo cual no impidió que padeciera agresiones por parte de un regidor de la Comisión de Seguridad Pública:

Cuando ganamos sí hubo mucho descontento de parte ellos, me amenazaron de muerte, dijeron que iban a matar a mi hijo si no dejaba el puesto. En ese tiempo trabajaba en Icatver y fueron presented any work to me". "Mr. Mayor, how can I present work to you if in order to do it I need the necessary tools to be able to move? You don't provide even a vehicle to do my rounds; if I go all morning to supervise sewers, drains and all of that, you go to the radio and say that I don't work, and ask if I don't feel ashamed to simply come in and collect my wages". At all times he has presented obstacles and has discredited me with newspaper articles throughout the year. I decided to make it known to the Congress and the Institute, but the truth is I haven't received the support I'd like and this makes me feel helpless because I ask myself what I'm doing here if this man does not allow me to perform the work I want to. I don't have any support of any kind; they don't even give me travelling allowances, nothing.

Another regidora documents a different case of haggling of her functions and struggling with her commissions, attitudes of verbal aggression and discrimination; and she even presented a lawsuit against the mayor because he didn't invite her to the council meetings:

At the beginning of the administration, the first fifteen days, there was a good relationship with the Mayor. I was assigned to six commissions, among them Education; Drinking Water; Public Cleaning; but because I did not agree to the management he wanted to give them, the mayor spoke to me and said that in order to justify my presence in the town council he was going to assign me the Citizen Participation commission. I imagine that he saw in the organic law that it didn't have that many functions and decided to assign me to that one, and Transit. In my municipality there is no transit; it is, rather, a path that belongs to the State Road Committee, a passageway. Thank God I tried to get information from the state and other municipalities in the Republic; I found out that the Citizen Participation Commission is useful for many things and I got involved in every area: managing prints and food stamps, as well as painting parks and balconies; with what other mayors and people from the civil society provided, I had access to plenty resources, but unfortunately, because it was not good for the mayor and he doesn't like my party, even I 
a ver a mi director para ver si tenía o no permiso pero, gracias a Dios, él era tan bueno que me ayudó mucho; trataron de moverme, pero no pudieron porque era un cargo de elección popular. Después de esto continuaron hablándome y me seguían amenazando, siendo ya regidora. Fueron a ver al presidente municipal que había quedado, quien les dijo: "no, ella fue elegida y se va quedar"; también le ofrecieron dinero, pero él les contestó: "ella tiene buena presentación aquí, tiene buena imagen en (...), sé que es una persona a la que le gusta mucho trabajar y va a continuar". Hubo amenazas también hacia él, pero el presidente se mantuvo firme.

El que se encarga de la Comisión de Protección Civil es un capitán retirado; fuimos al ejército, investigaron y se dieron cuenta que eran estas personas. Entonces, el general me dijo: "el próximo anónimo me lo das y yo voy a tomar cartas en el asunto". Me pusieron soldados en mi casa y un muchacho con un cañón ahí para que me viera porque recibía amenazas todos los días; cuando ellos vieron todo esto me dijeron quiénes eran los responsables. Ya que lo supe y estando un día cerca de uno de ellos, comenté: "si recibo alguna otra amenaza anónima no hay de qué preocuparse porque ya sabemos quiénes son". Todavía me volvieron a hablar por teléfono, pero yo les dije: "¿sabe qué? Ya tengo una denuncia con los dirigentes en Xalapa y la próxima vez me voy a ir contra ustedes". Esta gente es parte de los que participaron en la elección, pero gracias a Dios tenemos un buen presidente, maravilloso, que me ha tendido la mano en todo, siempre.

El caso más grave de violencia política fue el de una regidora indígena quien valientemente denunció la situación de su municipio y las múltiples irregularidades en que se incurría. La violencia política ejercida hacia ella llegó en este caso a extremos de gravedad, como amenazas de muerte e intentos de acusarla de delitos, etcétera.

Al siguiente día de que tomamos posesión del cargo me esperé toda esa jornada para hacer cabildo, al siguiente día tampoco hubo nada y así sucesivamente hasta hoy que se cumplen dos meses y hasta ahora nunca se ha hecho ningún cabildo. as a woman have representation and he also took away that commission.

Taking on the Transit commission has been very complicated, since I've had to do the work off the books, virtually hiding. I go to the schools but I don't divulge it because I know that they can take it away if they find out I'm working in it. The same happens with Gender Equity; they don't consider it important because there is none of that here, and I have received much maltreatment because I am a woman. In fact, when I was assigned to the Water Commission, they literally told me: "you stay in the water one because you are a woman, because you will deal with women, because you are the one who gossips and you can deal with them". There is currently a penal denunciation against the mayor because I have attended six council sessions in almost two years. They don't call me, they want to take my responsibility away; there are obviously witnesses and people, who are on our side and will support us, but all this causes fatigue that sometimes is hard to bear, and I have to learn to deal with it.

The following case presents greater violence related to taking possession of the position of regidora, to the displeasure of certain groups who subjected her to death threats; both her and her family. Finally, the intervention of a high army officer and the support from the municipal president, as well as the courageous attitude from the regidora, led to the end of the threats, which did not imply that she would not endure aggressions from a regidor in the Public Safety Commission:

When we won, there was a lot of unhappiness from them, they threatened to kill me, said they were going to kill my son if I did not step down from the position. At that time I worked at Icatver and they went to see my director to find out whether I had permission or not, but, thank God, he was so good that he helped me a lot; they tried to move me, but they couldn't because it was a position of popular election. After that they continued calling me and threatening me, once I was a regidora. They went to see the municipal president who had been elected, who 
Me han amenazado varias veces, por lo que ya le informé sobre esta situación a un Agente del Ministerio Público. Le pedí que investigara la situación a fondo.

Debo decir que sí cuento con apoyo en el municipio ya que, por ejemplo, el 13 de abril el alcalde inventó que yo tenía marihuana y me quitó el automóvil que traía; quería mandarme a la cárcel, pero no pudo pero y, gracias a Dios, la gente estuvo de mi lado.

Como se observa, el aislamiento y la exclusión, así como el intento de hacerla a un lado y quitarle el cargo ubicaron a esta regidora y a su familia en una situación delicada y peligrosa.

\section{REFLEXIONES FINALES}

Hemos visto cómo, en el ejercicio de su cargo, síndicas y regidoras enfrentan diversos obstáculos que van desde la escasez o la negación de recursos para realizar su trabajo hasta el acoso político, pasando por el bloqueo y el desconocimiento por parte de sus compañeros de cabildo o de los funcionarios municipales, el no ser escuchadas sus propuestas, enfrentar prejuicios y actitudes machistas, así como la desconfianza sobre sus capacidades por ser mujeres, ser jóvenes o de mayor edad e, incluso, por tener alguna discapacidad. Encontramos incluso algunos casos de acoso político que llaman la atención por el grado de violencia y de riesgo que implican para las regidoras y sus familias.

De esta manera, las representaciones sociales del poder político, que lo ubican como atributo "masculino" (Bourdieu, 2000), cuyos espacios estarían monopolizados por los varones, y a los que las mujeres "no pertenecen" de manera "natural", se expresan como mecanismos de exclusión de (Godelier, 1993), tanto en el camino para llegar a ocupar los cargos como a la hora de ejercerlos. Así, encontramos que, al ejercer el cargo, síndicas y regidoras comúnmente enfrentan una serie de dificultades específicas relacionadas con su situación como mujeres en el cabildo: falta de recursos para dar satisfacción a las necesidades básicas de la población y negación de los recursos para realizar las tareas propias de las comisiones de las que forman parte o dirigen; confrontación con los varones del cabildo y de la administración municipal, comenzando por el said: "no, she was elected and she will stay"; they also offered him money, but he responded: "she has good standing here, has a good image in (...), I know that she is a person who enjoys working very much and she will continue". There were also threats made against him, but the president was steadfast.

The one in charge of the Civil Protection Commission is a retired captain; we went to the army and they investigated and figured out who these people are. Then, the general told me: "bring me the next anonymous message you get, and I will take matters into my own hands". They placed soldiers at my house and a boy with a gun there so he could watch me, because I received threats every day; when they saw all this, they told me who was responsible. Once I knew and one day I was near one of them, I said: "if I receive another anonymous threat, I will have nothing to be worried about because we know who they are". They still called me on the phone, but I told them: "you know what? I presented a lawsuit against the leaders in Xalapa and the next time I will go against you". These people are part of those who participated in the election, but thank God we have a good president, wonderful, who has helped me in everything, always.

The gravest case of political violence was one with an indigenous regidora who courageously denounced the situation in her municipality and the multiple irregularities there were. The political violence exercised against her reached, in this case, grave extremes such as death threats and attempts to charge her with crimes, etcetera.

The day after we took possession of the position I waited that whole day to be in the council, the next day there was nothing again, and so on and so forth up to today that it has been two months, and until now there hasn't been a council meeting. I have been threatened several times, which is why I informed the Public Prosecutor's Agent about this situation. I asked him to investigate the situation fully.

I must say that I do have the support from the municipality because, for example, on April 13 
presidente municipal, generalmente un varón que en numerosas ocasiones no les reconoce su carácter de autoridades ni la legitimidad de su cargo. En algunos casos esto llega a extremos de violencia política (obligarlas o presionarlas para que hagan o dejen de hacer acciones propias de su cargo a través de amenazas, violencia física, etcétera), situación que se ha agudizado a partir del avance en la incidencia en los gobiernos municipales por parte de grupos de la delincuencia organizada, aunándose a las presiones comunes de los diversos cacicazgos y grupos de interés.

De esta manera resulta claro que si ya de por sí puede ser problemático llegar a ocupar un cargo, proponerse ejercerlo cabalmente y con apego a la ley orgánica municipal lo será aún más, pues ello significa exponerse a la confrontación y a presiones de diversos grupos de poder en medio de una cultura política que implica prácticas patrimonialistas y poco democráticas en los ayuntamientos y sus cabildos (Massolo, 2004 y 2008; Herrasti, 2003; Enzástiga, 2002; Rodríguez, 2000; Rodríguez y Cinta, 2003; Sam, 1998 y 2000; Valadez, 2003).

Hace más de tres lustros Veracruz comenzó a experimentar la alternancia partidaria en el poder a nivel municipal, aunque no a nivel estatal, prevaleciendo la hegemonía del PRI y la cultura política que le caracteriza. Como hemos visto, a este avance de la alternancia lo ha acompañado de manera contenida el de la pluralidad de género, muy limitado en las presidencias municipales, significativo en las sindicaturas y relevante en las regidurías. Los obstáculos para llegar al cargo y ejercerlo han sido documentados por las síndicas y regidoras, cuyos testimonios fueron abordados en nuestro estudio, y son semejantes a los encontrados en estudios sobre otras pertenecientes a otros estados (Barrera, 2008 y 2011a; Barrera y Massolo, 1998; Herrasti, 2003; Sam, 2002), resaltando en Veracruz cierto contexto conservador en cuanto a los roles masculino y femenino, como apuntara Cinta (2007), y una cultura política autoritaria de tipo corporativo y clientelar, de marcado peso priísta (Rodríguez, 2000; Rodríguez y Cinta, 2003; Cinta, 2007).

Resulta significativo que en los trabajos del Encuentro Estatal de Presidentas Municipales, Síndicas y Regidoras del Estado de Veracruz, realizado en 2009, se concluyera que las estrategias posibles frente a las situaciones de exclusión pasan por la capacitación (de síndicas y regidoras acerca de la administración municipal the mayor made a story up that I had marijuana and took the car I had away; he wanted to send me to jail, but he couldn't and, thank God, the people were on my side.

As can be observed, the isolation and the exclusion, as well as the attempt to drive her away and take the position from her, placed this regidora and her family in a delicate and dangerous situation.

\section{FinAL REFLECTIONS}

We have seen how, in the exercise of their position, sindicas and regidoras face various obstacles that range from scarcity or denial of resources to perform their tasks, to political harassment, including blocking and lack of recognition by their town council coworkers or the municipal officers, their proposals not being heard, facing prejudice and chauvinistic attitudes, as well as the mistrust regarding their abilities because they are women, young or older, and even, because of a disability. We even found some cases of political harassment that stand out because of the degree of violence and risk that they imply for the regidoras and their families.

Thus, social representations of political power, which place it as a "masculine" attribute (Bourdieu, 2000), whose spaces would be monopolized by males, and to which women "do not belong" in a "natural" manner, are expressed as mechanisms of exclusion (Godelier, 1993), both in the path to reach the positions and at the time of exercising them. Therefore, we find that when exercising their position, sindicas and regidoras commonly face a series of specific difficulties related to their situation as women in the town council: lack of resources to satisfy the basic needs of the population and denial of resources to perform the tasks related to the commissions they belong to or run; confrontation with the men in the council and the municipal administration, beginning with the municipal president, generally a male, who in many cases does not recognize their character as authorities or the legitimacy of their position. In some cases this reaches extremes of political violence (forcing them or pressuring them into doing or ceasing to undertake actions that are suitable to their position through threats, physical violence, etcetera), situation that has worsened since the advancement in 
y la Ley Orgánica del Municipio Libre del Estado de Veracruz, así como de los miembros del cabildo en cuanto a equidad de género), la organización de redes de mujeres con cargo en el cabildo más allá de las pertenencias partidarias, así como el empoderamiento de éstas como autoridades en el cabildo, denunciando el acoso y otras prácticas discriminatorias, subrayándose la importancia de la lucha por el cumplimiento de la ley orgánica municipal por parte de todos los miembros del cabildo y los funcionarios del gobierno municipal.

\section{NoTAS}

${ }^{1}$ Los municipios son: Cayucan, Altotonga, Atzacan, Atzalan, Ayahualulco, Banderilla, Chontla, Espinal, Gutiérrez Zamora, Ixhuatlán de Madero Ixhuatlancillo, Jilotepec, La Antigua, Martínez de la Torre, Medellín, Nogales, Oluta, Papantla, Pueblo Viejo, San Andrés Tuxtla, San Juan Evangelista, Soconusco, Teocelo, Tenochtitlán, Tlalnehuayocan, Tlapacoyan, Tres Valles, Villa Aldama, Zentla. The municipalities are: Cayucan, Altotonga, Atzacan, Atzalan, Ayahualulco, Banderilla, Chontla, Espinal, Gutiérrez Zamora, Ixhuatlán de Madero Ixhuatlancillo, Jilotepec, La Antigua, Martínez de la Torre, Medellín, Nogales, Oluta, Papantla, Pueblo Viejo, San Andrés Tuxtla, San Juan Evangelista, Soconusco, Teocelo, Tenochtitlán, Tlalnehuayocan, Tlapacoyan, Tres Valles, Villa Aldama, Zentla.

${ }^{2}$ Tomando en cuenta ambas formas de inserción, y el hecho de que formaban parte de tres a seis comisiones, encontramos que la participación más alta se dio en la comisión de Salud y Asistencia Pública, seguida de Ornato, Parques, Jardines y Alumbrado; siguiéndole la de Registro Civil, Panteones y Reclutamiento; y la de Educación, Recreación, Cultura, Actos Cívicos y Fomento Deportivo. Una participación menor, pero significativa, se dio en las comisiones de Tránsito y Vialidad; Limpia Pública; de Comercio, Centrales de Abasto, Mercados y Rastros; de Ecología y Medio Ambiente; Equidad de Género; de Agua Potable, Drenaje, Alcantarillado, Tratamiento y Disposición de Aguas Residuales y la de Participación Ciudadana y Vecinal. Hubo baja participación en las comisiones de Hacienda y Patrimonio Municipal; de Policía y Prevención del Delito; y de Protección Civil, en tanto que se registró una presencia marginal en las de Comunicación y Obras Públicas; Asentamientos the incidence of organized crime groups on municipal governments, in addition to the common pressures from the various chiefdoms and interest groups.

Therefore, it is clear that if it can be problematic to occupy a position, to attempt to exercise it fully and adhering to the municipal organic law will be even more difficult, because this entails being exposed to confrontation and pressures from diverse groups of power in the midst of a political culture that implies patrimonial and undemocratic practices in the town governments and their councils (Massolo, 2004 and 2008; Herrasti, 2003; Enzástiga, 2002; Rodríguez, 2000; Rodríguez and Cinta, 2003; Sam, 1998 and 2000; Valadez, 2003).

More than fifteen years ago, Veracruz began to experience party alternation in the power at the municipal level, although not at the state level, with the PRI hegemony prevailing as well as the political culture that is characteristic of this party. As we have seen, this advance in alternation has been accompanied in a contained manner with gender plurality, quite limited to municipal presidencies, significantly in sindicaturas and importantly in regidurias. The obstacles to reach the position and exercise it have been documented by the sindicas and regidoras, whose testimonies were analyzed in our study, and they are similar to those found in studies about other women in other states (Barrera, 2008 and 2011a; Barrera and Massolo, 1998; Herrasti, 2003; Sam, 2002), and it stands out that in Veracruz there is a certain conservative context in terms of the masculine and feminine roles, as Cinta (2007) points out, and an authoritarian political culture of corporative and clientele type, with marked PRI influence (Rodríguez, 2000; Rodríguez and Cinta, 2003; Cinta, 2007).

It is meaningful that in the works at the State Meeting of Municipal Presidents, Trustees and Councilors of the State of Veracruz (Encuentro Estatal de Presidentas Municipales, Sindicas y Regidoras del Estado de Veracruz), held in 2009, it was concluded that the possible strategies to face situations of exclusion include training (for sindicas and regidoras, regarding the municipal administration and Organic Law for the Free Municipality in the State of Veracruz, as well as for the council members in terms of gender equity), organizing networks of women in town councils beyond party affiliation, as well as empowering them as authorities in the council, 
Humanos, Fraccionamientos, Licencias y Regularización de la Tierra; Fomento Agropecuario; y de Gobernación, Reglamentos y Circulares, Derechos Humanos; Bares y Cantinas; y en la de Turismo. $\bullet$ Taking into account both forms of insertion, and the fact that they were part of three to six commissions, we find that the highest participation was in the Health and Public Assistance commission, followed by Beautification, Parks, Gardens and Streetlights; followed by Civil Registry, Cemeteries and Recruiting; and Education, Recreation, Culture, Civil Acts and Sports Promotion. A lower participation, although significant, was in the Transit and Roads commission; Public Cleaning; Commerce, Supply Centers, Markets and Slaughterhouses; Ecology and Environment; Gender Equity; Drinking Water, Drainage, Sewage, Treatment and Disposal of Residual Waters; and, Citizen and Neighbor Participation. There was low participation in the commissions of Taxes and Municipal Patrimony; Police and Crime Prevention; and Civil Protection; while there was marginal presence in those of Public Communication and Works; Human Settlements, Residential Development, Licensing and Land Regularization; Agricultural and Livestock Promotion; and Governance, Regulations and Notices; Human Rights; Bars and Canteens; and, Tourism.

\section{Literatura Citada}

Acosta Arévalo, Octavio. 2003. Manual de la Sindicatura Municipal. México, Centro de Servicios Municipales Heriberto Jara, A.C.

ACOBOL (Asociación de Concejalas de Bolivia). 2007. Guía de información y prevención contra el acoso político y la violencia de género en razón de género. La Paz, Bolivia, ACOBOL, UNFPA. www.acobol.org.bo, 2007.

Barrera Bassols, Dalia. 2003. Transgresiones, control social y violencia hacia las mujeres en el ámbito rural. In: GénEros, Año II, Número 31. Universidad Autónoma de Colima, octubre 2003.

Barrera Bassols, Dalia. 2007. Equidad de género y participación de las mujeres en los cargos de elección popular a 54 años del voto femenino. In: Sororidad, Núm. 1, Instituto Veracruzano de las Mujeres.

Barrera Bassols, Dalia (ed). 2008. I Encuentro estatal de presidentas municipales, síndicas y regidoras de los gobiernos municipales del estado de Guerrero. México. SEMUJER/ GIMTRAP A.C.

Barrera Bassols Dalia (ed). 2009. Encuentro estatal de presidentas municipales, síndicas y regidoras del estado de Veracruz. Memoria. México. Instituto Veracruzano de las Mujeres.

Barrera Bassols, Dalia. 2011a. Representaciones del poder y mecanismos de exclusión de las mujeres en los cabildos. Síndicas y regidoras guerrerenses. In: Dalia Barrera Bassols y denouncing harassment and other discriminatory practices, and underlining the importance of the struggle for compliance of the municipal organic law by all members of the town council and officers in the municipal government.

- End of the English version -

Raúl Arriaga Ortíz (eds), Género, Cultura, Discurso y Poder. México. Escuela Nacional de Antropología e Historia/ CONACULTA. pp: 137-153.

Barrera Bassols, Dalia. 2011b. Género, ciudadanía y gobiernos locales. Mujeres en los cabildos e instancias municipales de las mujeres en México. In: Mónica Cejas y Ana Lau Jaiven (coord) En la encrucijada de género y ciudadanía. Sujetos políticos, derechos, gobierno, nación y acción política. México, Universidad Autónoma Metropolitana/CONACYT. pp: 85-109.

Barrera Bassols, Dalia y Alejandra Massolo (coord). 1998. Mujeres que gobiernan municipios. Experiencias, aportes y retos. México, Programa Interdisciplinario de Estudios de la Mujer de El Colegio de México.

Barrera Bassols, Dalia y Alejandra Massolo (comp). 2003. El Municipio. Un reto para la igualdad de oportunidades entre hombres y mujeres. México, Inmujeres/PNUD/GIMTRAP A.C.

Barrera Bassols, Dalia, Irma Aguirre Pérez, y Denisse Casas Ortiz. 2008. Mujeres guerrerenses en el cabildo. Perfiles, trayectorias, logros y problemáticas de las mujeres en el municipio. In: Estudios y propuestas para el medio rural, Tomo IV, Universidad Autónoma Indígena de México/Colegio de Posgraduados Campus Montecillo/ Colegio de Posgraduados Campus Puebla.

Barrera Bassols, Dalia, y Blanca Suárez San Román. 2012. Los desafíos de llegar y de ejercer un cargo. Mujeres mexicanas en los albores del siglo XXI. In: Revista Ra Ximhai, enero-abril 2012. Vol. 8, Número 1, Universidad Autónoma Indígena de México.

Bourdieu, Pierre. 2000. La dominación masculina. Barcelona. Anagrama.

Cinta Loaiza, Dulce María. 2007. Género y participación política de las veracruzanas: entre lo público y lo privado, Tesis Doctoral, Departamento de Ciencia Política y Relaciones Internacionales, Facultad de Derecho, Universidad Autónoma de Madrid.

Código Electoral para el estado de Veracruz de Ignacio de la Llave, Instituto Electoral Veracruzano, en www.rev.org.mx/ archivos/reglamentacion/codigo307/codigo307b.pdf. Número 307. consulta del 16 de septiembre de 2010.

Godelier, Maurice. 1993. Las mujeres y el poder político. In: Antropológicas, Núm. 7, Nueva Época.

Enzástiga Santiago, Mario, Concepción Torres Zaragoza, y Jaime Martínez Rosiles. 2002. Manual El Cabildo y sus modalidades. México, Centro de Servicios Municipales Heriberto Jara, A.C.

Grupo Parlamentario del PRD/Cámara de Diputados LVII Legislatura/ Congreso de la Unión, Instituto de Desarrollo Municipal, Partido de la Revolución Democrática, 2000. El 
ABC del gobierno municipal. México, Grupo Parlamentario del PRD/Cámara de Diputados LVII Legislatura/ Congreso de la Unión.

Herrasti Aguirre, María Luisa. 2003. Manual del Regidor y la Regidora. México, Centro de Servicios Municipales Heriberto Jara, A.C.

Ley Orgánica del Municipio Libre del estado de Veracruz. 20010. Última reforma publicada en la Gaceta Oficial: 22 de abril.

Massolo, Alejandra. 2004. Regidoras y síndicas en el Cabildo. In: Dalia Barrera Bassols, Alejandra Massolo, Irma Aguirre Pérez, Guía para la equidad de género en el municipio. México, GIMTRAP A.C./Indesol. pp: 81-94.

Massolo, Alejandra. 2008. El derecho y el reto de las mujeres a participar en el gobierno de los municipios. El papel de las regidoras. In: Dalia Barrera Bassols (ed), I Encuentro estatal de presidentas municipales, síndicas y regidoras de los gobiernos municipales del estado de Guerrero. México, SEMUJER/GIMTRAP A.C. pp: 136-164.

Rodríguez Villafuerte, Beatriz. 2000. Mujeres y participación ciudadana en un Ayuntamiento panista: Córdoba, Veracruz. In: Dalia Barrera Bassols (comp), Mujeres, ciudadanía y poder. México, Programa Interdisciplinario de Estudios de la Mujer de El Colegio de México. pp: 227-293.

Rodríguez Villafuerte, Beatriz, y Dulce Cinta Loaiza. 2003. Una aproximación a la participación política femenina en los municipios del estado de Veracruz. In: Dalia Barrera Bassols y
Alejandra Massolo (comp), El municipio. Un reto para la igualdad de oportunidades entre hombres y mujeres. México, GIMTRAP A.C./Inmujeres/PNUD. pp: 173-212.

Sam Bautista, Magdalena. 1998. Mujeres gobernando en Veracruz: tres estudios de caso. In: Dalia Barrera Bassols y Alejandra Massolo (coord), Mujeres que gobiernan municipios. Experiencias, aportes y retos. México: Programa Interdisciplinario de Estudios de la Mujer de El Colegio de México. pp: 63-89.

Sam Bautista, Magdalena. 2000. Mujeres gobernantes: los casos de Banderilla, Coatepec y Gutiérrez Zamora, Veracruz. In: Dalia Barrera Bassols (comp), Mujeres, ciudadanía y poder. México, Programa de Estudios de la Mujer de El Colegio de México. pp: 161-226.

Sam Bautista, Ma. Magdalena. 2002. Mujer y gobierno municipal. Factores que ayudan o dificultan la participación femenina en los Ayuntamientos de Tlaxcala. 1999-2001. México, Universidad Autónoma de Tlaxcala/CONACYT.

Sam Bautista, Ma. Magdalena. 2003. Participación política de las mujeres en los ayuntamientos: el caso de Tlaxcala. In: Barrera Bassols, Dalia y Massolo, Alejandra (comp). El municipio. Un reto para la igualdad de oportiunidades entre hombres y mujeres. México. GIMTRAP A.C./Inmujeres/PNUD. pp: 213-235.

Valadez García, Lina. 2003. Vivencias desde la regiduría. In: Vélez Andrade, Haydée (comp) Mujer y Gobierno. México. Centro de Servicios Municipales "Heriberto Jara"/Fons Catalá de Cooperació al Desenvolupement. pp: 101-108. 